\title{
Subcutaneous Toxicity of Agmatine in Rats
}

\section{Sıçanlarda Subkütan Agmatin Toksisitesi}

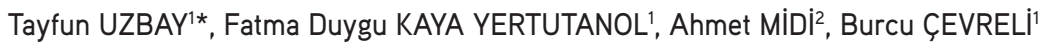 \\ "Üsküdar University, Neuropsychopharmacology Application and Research Center, (NPARC), İstanbul, Turkey \\ Bahçeșehir University, Faculty of Medicine, Department of Pathology, İstanbul, Turkey
}

\begin{abstract}
Objectives: The aim of this study was to investigate the effects of repetitive agmatine administration on sensorimotor gating in rats first but, as unexpected, ulcerative necrotic cutaneous lesions appeared, thus, the study was directed primarily to clarify these results.

Materials and Methods: In the first set of experiments, we administered agmatine (40,80 and $160 \mathrm{mg} / \mathrm{kg}$ ) and saline (control group) subcutaneously to male Wistar albino rats ( $n=8$ for each group) for 14 consecutive days. Ulcerative necrotic cutaneous lesions appeared following the third day of agmatine administration. We decided to explore the potential toxic dermal effects of agmatine and conducted second set of experiments with two groups $(n=8)$ to compare the effects of subcutaneous vs. intraperitoneal agmatine $(80 \mathrm{mg} / \mathrm{kg})$ injection to understand if the injection route determines the toxicity.

Results: Our results showed that prolonged subcutaneous but not intraperitoneal administration of agmatine leads to a delayed dermal reaction in rats. Histopathologic examination of skin samples revealed cutaneous aseptic necrosis at the injection site whereas blood tests were found to be normal.

Conclusion: This finding is important to point out the risks of prolonged subcutaneous administration of agmatine to rats within the concept of animal welfare. In addition, the results raise questions about the possible risks of over-the-counter use of agmatine among humans although the agent is taken via oral route.
\end{abstract}

Key words: Agmatine, skin reaction, subcutaneous route, toxicity, rat

Öz

Amaç: Bu çalışmanın amacı sıçanlarda ilk kez tekrarlayan agmatin uygulamasının sensorimotor kapılama sistemi üzerine etkilerini incelemekti, ancak subkütan uygulamada karşımıza çıkan beklenmedik ülseratif nekrotik lezyonlar bu konuya odaklanmamıza neden oldu.

Gereç ve Yöntemler: İlk grup deneylerde, erkek Wistar albino sıçanlara 14 gün süreyle subkütan yoldan agmatin (40, 80 ve 160 mg/kg) veya salin (kontrol grubu) enjeksiyonu yapıldı ( $n=8$ her bir grup). Uygulamaların üçüncü gününden itibaren agmatin verilen gruplarda ülseratif nekrotik deri lezyonları gözlendi. Bu etkilerin dermal bir reaksiyona bağlı olup olmadığını anlamak için ayrı bir denek grubuna aynı protokolle agmatin (80 mg/kg) intraperitoneal yoldan verildi ( $n=8$ her bir grup).

Bulgular: Bulgularımız subkütan yoldan verilen agmatinin geç dönemde ortaya çıkan bir dermal reaksiyona neden olurken, intraperitoneal uygulamanın böyle bir etki oluşturmadığına işaret etti. Lezyon gözlenen deneklerden alınan deri örneklerinin histopatolojik incelemesinde, enjeksiyon yerindeki deride aseptik nekroz saptanırken, bu deneklerin kan testleri normal bulundu.

Sonuç: Bu bulgu sıçanlarda uzun süreli subkütan agmatin uygulamasının denek refahı bakımından risk oluşturan toksik bir etkiye neden olduğuna işaret etmektedir. Bu bulgu insanlarda oral yoldan reçetesiz olarak alınabilen agmatinin bazı potansiyel riskleri olabileceği konusunda sorular ortaya çıkarmaktadır.

Anahtar kelimeler: Agmatin, deri reaksiyonu, subkütan yol, toksisite, sıçan

*Correspondence: E-mail: uzbayt@yahoo.com, Phone: +90 3123044767

Received: 17.11.2016, Accepted: 02.02.2017

-Turk J Pharm Sci, Published by Galenos Publishing House. 


\section{INTRODUCTION}

Agmatine is a polyamine that is produced through decarboxylation of L-arginine by the enzyme arginine decarboxylase. It interacts to various receptors and has been accepted as a new neurotransmitter in brain. In experimental studies, agmatine exhibited neuroprotective, anticonvulsant, antinociceptive, anxiolytic and antidepressant-like actions in central nervous system (CNS). It also generates some favorable effects on cerebral damages and withdrawal syndromes involved in addictive drugs. ${ }^{1-6}$

Agmatine binds $\alpha 2$-adrenoceptors and imidazoline receptors and blocks ligand-gated cation channels like cholinergic, nicotinic, serotonergic and NMDA receptors. ${ }^{6}$ One of the important psychiatric disorders is schizophrenia. Schizophrenia is a severe mental disorder regarding impairment of sensorimotor gating system. ${ }^{7}$ In some studies, a single dose of $160 \mathrm{mg} /$ $\mathrm{kg}$ agmatine by ip route was found to disrupt the prepulse inhibition (PPI) of acoustic startle reflex in rats. ${ }^{8}$ Disruption of PPI is related to sensorimotor gating deficits. In addition, plasma levels of agmatine in patients with schizophrenia were found to be almost three-fold elevated compared to healthy subjects. ${ }^{9}$ Because PPI is an available tool for sensorimotor gating deficits, agmatine may have some toxic effects on sensorimotor system which is not proven yet.

Although various studies on experimental animals indicated that agmatine has some beneficial pharmacological effects 5,6 several polyamines such as putresin, spermine and spermidine which are also metabolites of agmatine elicit some toxic effects in both animals and human. ${ }^{10-16}$ It is well-known that fermented foods contain high levels of polyamines such as cheese, fermented fish and meat, wine, beer, and fermented vegetables and some non-fermented foods such as fish, meat, fruits, juices, and vegetables have a considerable amount of polyamines..$^{17}$ Some bioamines are also considered as an indicator of microbial contamination in foods. ${ }^{18}$ Agmatine which is produced especially during the fermentation of alcohol (wine and beer in particular) is known to increase the histamine toxicity in humans. ${ }^{18-20}$

Although polyamines may have possible toxic effects, some polyamines such as agmatine is used as over the counter medications or dietary supplement products. Agmatine has been used as a dietary supplement for promoting the functions of both the peripheral and CNS. ${ }^{21-23}$ There are several agmatine containing commercial products that are marketed as nutraceuticals.

In our laboratory, investigating the effects of repetitive (14 days) administration of different doses of agmatine on sensorimotor gating were decided in rats. After we started the test protocol with $160 \mathrm{mg} / \mathrm{kg} /$ day alternating intraperitoneal/subcutaneous injections of agmatine, we noticed severe skin lesions of rats after subcutaneous injections. These lesions appeared in all subjects at the second or third day of drug administration. The same lesions were also seen in other agmatine groups but not in the subjects of saline treated control group. In this context, we organized a second set of experiments to investigate this skin reaction in detail. Because this statement may have important public health relevance, the main goal of the present study if agmatine administration by subcutaneous route has some unpredictable harmful effects in rats. Here we report the injection site reaction (ISR) after subcutaneous administration of agmatine in rats and discuss the possible toxic effects of agmatine.

\section{MATERIALS AND METHODS}

\section{Animals and laboratory conditions}

In this study, adult male Wistar albino rats were used as the test animals. The animals were obtained from Üsküdar University Experimental Research Unit (ÜSKÜDAB, İstanbul, Turkey). All experiments were performed in Neuropsychopharmacology Application and Research Center of Üsküdar University. Animals were kept under controlled conditions (temperature, $22 \pm 2^{\circ} \mathrm{C}$; humidity, $50 \pm 5 \%$; and a $12 \mathrm{~h}$ light/dark cycle, lights on from 07:00 to 19:00 h). The animals had free access to tap water and standardized pellet food throughout the procedures. All experiments were performed at the same time of day and during the light period. All the experiments were conducted according to the ethical rules in Helsinki Declaration and Guide for the Care and Use of Laboratory Animals as adopted by the National Institutes of Health, USA, which was published and released in 1996. In addition, this study was approved by the Local Ethic Committee of the Üsküdar University on 20.10.2015 with a decision number 2015-07. The ethical permissions included in additional tests.

\section{Study protocol}

The test animals assigned into several groups randomly $(n=8$ for each group). The study had two sets of experiments that began with four groups (Table 1). Agmatine sulfate (Sigma Chemicals Co, USA) was dissolved in $1 \mathrm{~mL}$ saline and administered 160 , 80 and $40 \mathrm{mg} / \mathrm{kg} /$ day to animals for 14 consecutive days in two times a day. In order to prevent the risk of peritonitis, the drug was injected intraperitoneally in the morning and subcutaneously in the evening. Saline was injected as a vehicle two times a day to the control group. At the third day of agmatine treatments, skin lesions were appeared almost in all animals.

After 14 days of agmatine administration, all animals were decapitated under anesthesia (xylazine plus ketamine) and both blood samples and skin biopsies were collected. Complete blood count, renal and liver function tests were performed to assess metabolic function. The skin biopsies were evaluated by an experienced pathologist.

After the experiments were terminated, second set experiments were performed with two new groups of animals ( $n=8$ for each group) to determine whether the lesions were related to the route of administration of agmatine. Agmatine $80 \mathrm{mg} / \mathrm{kg} / \mathrm{day}$ was given intraperitoneally to one group and subcutaneously to the second group for one week. Post-mortem examination of the abdominal cavity and organs following the termination of experiments revealed any obvious abnormalities. Saline 
injections were done by the same routes of agmatine in all experiments.

\section{RESULTS}

\section{Skin lesions}

At the second or third day after the initiation of injections, most of the dorsal skin of the animals of agmatine $160 \mathrm{mg} / \mathrm{kg} / \mathrm{day}$ group was observed to turn black without any hair loss. One or two days after this observation, annular hemorrhagic ulcerative lesions appeared on the dorsal skin with prominent hair loss over it. The lesion sites were limited to injections sites and around. All animals had one or more lesions with diameter of $1.5 \mathrm{~cm}$ to $2.5 \mathrm{~cm}$ (Table 1). During the 14 days period, old lesions healed with crust formation resulting hair loss over it but new lesions continue to emerge with ongoing drug administration. Only 6 animals in the agmatine $80 \mathrm{mg} / \mathrm{kg} /$ day group showed similar lesions with diameter of $1 \mathrm{~cm}$ to $2 \mathrm{~cm}$ (Table 1). On the other hand, similar lesions within the same range of diameters were observed in the 5 animals of the agmatine $40 \mathrm{mg} / \mathrm{kg} /$ day group (Table 1). There were no skin lesions in the saline treated group. The general health of all animals was good and vital signs were between normal ranges.

In the second set of experiments, no skin lesions were observed in the animals of intraperitoneal agmatine $80 \mathrm{mg} /$ $\mathrm{kg} /$ day treated group. On the other hand, all animals of the subcutaneous agmatine $80 \mathrm{mg} / \mathrm{kg} /$ day treated group developed the similar skin lesions with a diameter of $1.5-2.5 \mathrm{~cm}$ on the second day which continue to progress and the number of the lesions were between one and three (Table 1). A skin lesion at the fifth day of agmatine administration is shown in Figure 1. These experiments revealed that subcutaneous administration of agmatine may have toxic effects on rats.

\section{Blood tests}

There were no prominent differences between control and agmatine groups in terms of complete blood count, C-reactive protein, renal and liver function tests (for liver and kidney function test results see Table 2). Blood tests were not performed during second set of experiments.

\section{Biopsies}

In half of the cases, there were changes secondary to bacterial infection (purulent exudate collection, bacteria cluster, prominent dermal edema and neutrophil infiltration). These changes were also present in subcutaneous tissue. Noncomplicated cases showed subcutaneous vascular thrombosis, epidermal and dermal necrosis, hyalinization in the dermal collagen, mild perivascular lymphocyte infiltration, and basal epidermal separation in the epithelia that located around the ulcer (Figure 2). The histopathologic examination of lesions was compatible with injection site cutaneous aseptic necrosis.

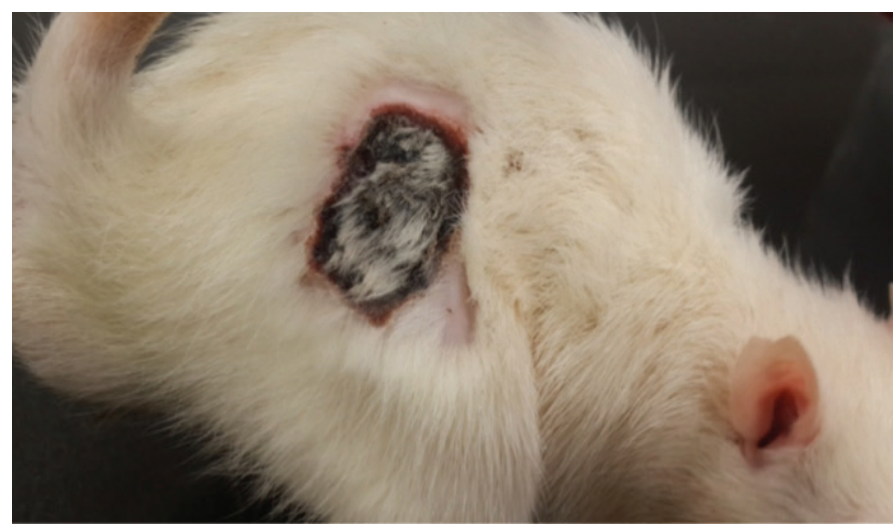

Figure 1. A lesion at the back skin of a subject in group 5 Table 1. Summary of study protocol

\begin{tabular}{|c|c|c|c|c|c|c|c|c|c|c|c|}
\hline 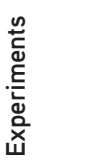 & $\begin{array}{l}\text { Groups } \\
n=8\end{array}$ & Agent & $\begin{array}{l}\text { Total } \\
\text { Dose }\end{array}$ & $\begin{array}{l}\text { Total } \\
\text { given } \\
\text { volume* }\end{array}$ & Route & $\begin{array}{l}\text { Duration } \\
\text { (days) }\end{array}$ & $\begin{array}{l}\text { Animals } \\
\text { with skin } \\
\text { reactions } \\
\text { (n) }\end{array}$ & $\begin{array}{l}\text { Number of } \\
\text { skin lesions } \\
\text { (n) }\end{array}$ & $\begin{array}{l}\text { Lesion } \\
\text { size } \\
(\mathrm{cm})\end{array}$ & $\begin{array}{l}\text { Blood } \\
\text { tests }\end{array}$ & Biopsies \\
\hline \multirow{4}{*}{ 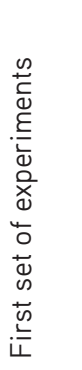 } & 1 & Agmatine & 160 mg/kg/day & $1 \mathrm{~mL} / \mathrm{day}$ & $\begin{array}{l}\text { Alternate } \\
\text { i.p./s.c.** }\end{array}$ & 14 & 8 & 1 or 2 & $1.5-2.5$ & + & + \\
\hline & 2 & Agmatine & 80 mg/kg/day & 1 mL/day & Alternate i.p./s.c. & 14 & 6 & 1 or 2 & $1-2$ & + & + \\
\hline & 3 & Agmatine & 40 mg/kg/day & $1 \mathrm{~mL} /$ day & Alternate i.p./s.c. & 14 & 5 & 1 & $1-2$ & + & + \\
\hline & 4 & Saline & - & $1 \mathrm{~mL} /$ day & Alternate i.p./s.c. & 14 & - & - & - & + & - \\
\hline \multirow{2}{*}{ 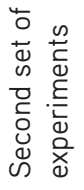 } & 5 & Agmatine & 80 mg/kg/day & $1 \mathrm{~mL} /$ day & S.C. & 7 & 8 & 1 or 3 & $1.5-2.5$ & - & - \\
\hline & 6 & Agmatine & 80 mg/kg/day & $1 \mathrm{~mL} /$ day & i.p. & 7 & - & - & - & - & - \\
\hline
\end{tabular}

${ }^{*}$ Agmatine was dissolved in saline and given as $0.5 \mathrm{~mL}$ solution to subjects two times a day.

**ip.: Intraperitoneal; s.c.: Subcutaneous 
Table 2. Liver and kidney function test results of rats

\begin{tabular}{llllll} 
Group & Rat & $\begin{array}{l}\text { AST } \\
\mathrm{U} / \mathrm{L}\end{array}$ & $\begin{array}{l}\text { ALT } \\
\mathrm{U} / \mathrm{L}\end{array}$ & $\begin{array}{l}\mathrm{BUN} \\
\mathrm{mg} / \mathrm{dL}\end{array}$ & $\begin{array}{l}\text { Creatinine } \\
\mathrm{mg} / \mathrm{dL}\end{array}$ \\
\hline 1 & 1 & 156.6 & 69.3 & 11.8 & 0.2 \\
Agmatine & 2 & 180.1 & 61.5 & 13.6 & 0.2 \\
$160 \mathrm{mg} / \mathrm{kg} / \mathrm{day}$ & 3 & 236.5 & 83.9 & 13.3 & 0.2 \\
& 4 & 181.5 & 61.8 & 13.4 & 0.2 \\
& 5 & 156.6 & 67.9 & 12.1 & 0.2 \\
& 6 & 146.0 & 47.7 & 12.0 & 0.2 \\
& 7 & 211.7 & 124.9 & 14.2 & 0.2 \\
& 8 & 239.5 & 82.6 & 12.1 & 0.2
\end{tabular}

\begin{tabular}{llllll}
\hline 2 & 1 & 118.3 & 79.8 & 19.1 & 0.2 \\
& 2 & 134.6 & 81.5 & 16.8 & 0.2
\end{tabular}

$\begin{array}{llllll}\text { Agmatine } & 3 & 142.2 & 97.8 & 20.0 & 0.3\end{array}$

$\begin{array}{llllll}80 \mathrm{mg} / \mathrm{kg} / \mathrm{day} & 4 & 114.6 & 89.9 & 17.2 & 0.2\end{array}$

$\begin{array}{llll}116.5 & 87.1 & 16.2 & 0.2\end{array}$

$\begin{array}{llll}130.8 & 81.6 & 16.4 & 0.2\end{array}$

$\begin{array}{llll}111.5 & 69.5 & 16.8 & 0.2\end{array}$

$\begin{array}{llll}111.7 & 92.3 & 18.5 & 0.3\end{array}$

\begin{tabular}{llllll}
\hline 3 & 1 & 109.3 & 68.1 & 19.4 & 0.3 \\
Agmatine & 2 & 141.0 & 75.0 & 20.8 & 0.3 \\
$40 \mathrm{mg} / \mathrm{kg} /$ day & 3 & 108.6 & 76.1 & 17.8 & 0.2 \\
& 4 & 113.7 & 81.1 & 17.0 & 0.3 \\
& 5 & 108.0 & 75.6 & 22.1 & 0.3 \\
& 6 & 129.7 & 71.6 & 19.8 & 0.2 \\
& 7 & 131.2 & 98.9 & 23.1 & 0.2 \\
& 8 & 131.4 & 82.4 & 19.6 & 0.3 \\
4 & & & & & \\
Saline & 1 & 241.6 & 74.3 & 18.8 & 0.5 \\
& 2 & 226.8 & 60.4 & 14.9 & 0.2 \\
& 3 & 142.7 & 60.0 & 14.7 & 0.2 \\
& 4 & 321.3 & 96.7 & 18.9 & 0.3 \\
& 5 & 187.3 & 68.5 & 19.6 & 0.5 \\
& 6 & 142.0 & 69.5 & 16.2 & 0.3 \\
& 7 & 178.7 & 64.4 & 14.8 & 0.2 \\
& 8 & 219.9 & 62.7 & 14.8 & 0.3 \\
\hline
\end{tabular}

AST: Aspartate aminotransferase; ALT: Alanine aminotransferase; BUN: Blood urea nitrogen

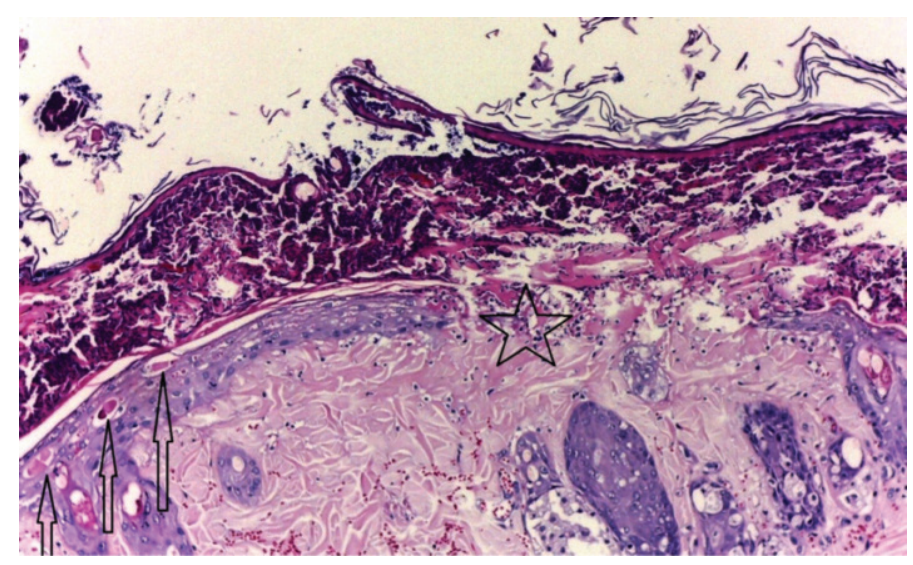

Figure 2. Splitting at the dermoepidermal junction in epidermis, purulent exudate on surface with neutrophil infiltration, necrotic cells in epidermis (an arrow), epidermal necrosis and ulcer with fibrinopurulent exudate (indicated with a star), dermal collagen hyalinization, hemorrhage in dermis in $160 \mathrm{mg} / \mathrm{kg} /$ day agmatine group (hematoxylin and eosin stain x100)

\section{DISCUSSION}

Our results clearly showed that subcutaneous agmatine administration to rats caused a serious skin reaction with prominent lesions. This is the first observation reported in literature that demonstrates the toxic effects of repetitive agmatine administration to rats. This unexpected and harmful effect of agmatine seems to be related to the route of administration due to the lack of similar observation by intraperitoneal route. In addition, we detected multiple lesions with cutaneous and subcutaneous changes by histopathological methods, thus this unexpected effect seems to be a regular ISR.

Polyamines are positively charged molecules that are prevalent among living organisms and derived from ornithine, methionine, arginine and lysine. ${ }^{24}$ They bind to several negatively charged molecules in cells to conduct vital processes. They have various roles in cell function as cell growth and proliferation, regulation of ion channels, protein and nucleic acid synthesis, regulation of gene expression, protection of cell components and antioxidative effects. ${ }^{25-30}$ On the other hand, polyamine levels are under critical control to prevent its potential toxic effects. It is indicated that beside direct effects of excess polyamine levels, some reactive aldehydes and reactive oxygen species that are produced with the catabolism of polyamines may also lead to toxicity. ${ }^{31}$ In a tissue culture study, it was shown that accumulation of polyamines may result in an apoptotic process where hydrogen peroxide is overproduced. ${ }^{32}$ The neurotoxicity, nephrotoxicity, hepatotoxicity, inflammatory effects can occur because of polyamine oxidation. ${ }^{31}$

Agmatine, a polyamine, is a widely-used workout supplement especially among body builders. The use of agmatine as an ergogenic aid is based on its nitric oxide modulating, cardio protective and hypoglycemic effects. ${ }^{33,34}$ Beside this, it was reported that agmatine has potentiating effect on morphineinduced analgesia in mice. ${ }^{3}$ Therefore, analgesic features of agmatine which encourage people to push the sports limits made this polyamine very popular among athletes. The agmatine sulfate powders or pills generally contain $250-750 \mathrm{mg}$ agmatine sulfate per serving where daily intake can be up to $7500 \mathrm{mg} /$ day. ${ }^{35}$ There are limited studies or case reports which stated that long-term agmatine use is safe in humans. ${ }^{23,35}$ In one case, a daily dose of $2.67 \mathrm{~g}$ oral agmatine sulfate for 5 years was reported to be safe without evidence of any adverse effects. The authors indicated that the periodic physical examinations and laboratory analyses revealed no adverse reactions. ${ }^{23}$ In another randomized, double-blind, placebo-controlled clinical study including patients with lumbar disc-associated radiculopathy, the same dose of oral agmatine $(2.67 \mathrm{~g})$ were given for 14 days. In this study, only three patients had mild-to-moderate diarrhea and nausea as adverse effects. ${ }^{35}$ On the other hand, limited animal studies also introduced evidence about the safety of agmatine ${ }^{36}$ In an animal study, oral agmatine sulfate administration with a daily dose of $100 \mathrm{mg} / \mathrm{kg} /$ day of adult Wistar albino rats for 95 days was reported to be also safe. ${ }^{36}$ In other two studies performed on Sprague-Dawley rats agmatine sulfate were administrated at $40 \mathrm{mg} / \mathrm{kg}$ dose intraperitoneally as once daily injections for 42 and 17 consecutive days. No 
skin lesions were reported. ${ }^{37,38}$ From the available evidence, it appears that oral and intraperitoneal administration of agmatine does not lead to a major toxicity in rodents and human beings.

On the contrary, we observed severe skin lesions with agmatine administration in rats. Adverse cutaneous drug reactions are skin and/or mucosa reactions with various morphologies which are triggered with systemic administration of drugs in appropriate doses. These reactions may be classified as non-immunologic and immunologic drug reactions. Nonimmunologic drug reactions have not immunologic processes and sensitization is not required for this kind of reactions. ${ }^{39,40}$ However immunologic drug reactions have type 1 , type 2 , type 3 or type 4 immunologic processes in sensitive individuals. ${ }^{39}$ The adverse drug reactions triggered with subcutaneous administration of drugs are called ISRs. These may include mild reactions like erythema and induration or may progress to ulcerations as in our study. The possible immune reaction that underlies the ISR is type IV (delayed) hypersensitivity which is mediated by antigen-specific effector $\mathrm{T}$ cells and becomes apparent 48-72 h after antigen exposure. ${ }^{41}$ Although immuno-histochemical analysis was not performed, delayed onset of lesions (48-72 hours after administration of agmatine) and histopathologic results suggest that this process could be associated with type 4 hypersensitivity reaction.

Delayed hypersensitivity reactions of skin are often induced by dermal or intradermal exposure to small lipophilic chemicals (haptens) with a molecular weight less than 500 Daltons. ${ }^{42}$ Haptens are molecules that can not elicit an immune response due to their small molecular weight often less than $1 \mathrm{kDa}$ and need to bind to a protein to become antigenic. ${ }^{41}$ Probably agmatine sulfate served as a hapten with its small molecular weight (228 Da) and lipophilic structure and bind to the dermal proteins to form neoantigens. Although the sensitizing potential of a hapten can not be reliably determined by its chemical structure, it was shown that most haptens react with amine $(\mathrm{NH} 2)$ or thiol $(\mathrm{SH})$ groups of skin proteins. ${ }^{43}$ Another possible mechanism can be the metabolization of the potential haptens to reactive metabolites by cutaneous enzymes, however agmatine metabolizing enzymes are absent in cutaneous tissue. Also, one can point out the potential toxic effect of sulfate component of agmatine, but there are several well-known drugs that are used safely via subcutaneous injection such as morphine sulfate and heparine sulfate in humans. To our knowledge, the repeated subcutaneous administration of sulfate containing agents to rodents seem to be harmless to the skin or other tissues of the subjects. ${ }^{44,45}$ Hence we assume that sulfate component doesn't seem to be responsible for mentioned skin lesions in this study.

Because lower doses of agmatine were related to a less number of injured rats, the harmful effect of agmatine observing in our study seems to be dose dependent. Thus, we did not test lower doses of agmatine than $40 \mathrm{mg} / \mathrm{kg}$ in the present study. Because all our subjects in the $160 \mathrm{mg} / \mathrm{kg} / \mathrm{day} \mathrm{ip} / \mathrm{sc}$ agmatine treated group and $80 \mathrm{mg} / \mathrm{kg} /$ day sc agmatine treated group developed similar skin lesions, we claim that agmatine act as a potent hapten in cutaneous/subcutaneous tissue. There are some drugs which may lead to ISRs in human like HIV-1 fusion inhibitor enfuvirtide, interferons, anti-TNF drugs adalimumab and etanercept. ${ }^{46-49}$ Most of these ISRs are mild as erythema and self-limited, whereas necrotic ulcerative lesions of skin are rare. There are human cases of cutaneous necrotic ulcers related with subcutaneous administration of polyethyleneglycol modified (pegylated) interferon-a-2b,50,51 interferon beta- $1 b,{ }^{52}$ and enoxaparine sodium. ${ }^{53}$ Nevertheless, the overall rate of skin ulcers among ISRs is relatively rare. On the other hand, agmatine administration elicited severe lesions in a dosedependent manner in most of the animals in our study, which may be specific to rats for sure. The lack of immuno-histochemical evaluation of skin samples is the major limitation of this study. Even so, this study is important because although agmatine is reported to be safe in mammals, we showed its potential toxic effects in rats when administrated subcutaneously.

\section{CONCLUSION}

In conclusion, our results suggest that subcutaneous injection of agmatine cause harmful skin reaction in rats. As subcutaneous administration is one of the commonly used delivery routes among animals, researchers should be cautious with this route while using agmatine. Further research is needed to reveal the underlying mechanism of agmatine related cutaneous/ subcutaneous toxicity via using immunohistochemical methods. Although this study doesn't provide any data related to the potential toxicity of agmatine among humans and agmatine is commonly used via oral route, we suggest that health professional need to be attentive to possible uncommon routes of administration of agmatine.

\section{ACKNOWLEDGEMENTS}

This study has been partially supported by Scientific and Technological Research Council of Turkey (TUBITAK) (Project No: SBAG - 110S344). We also thank our colleague Illknur Bozkurt M.D. from NP-İstanbul Neuropsychiatry Hospital who provided biochemistry analysis of the blood samples of the rats.

Conflict of Interest: No conflict of interest was declared by the authors.

\section{REFERENCES}

1. Cabella C, Gardini G, Corpillo D, Testore G, Bedino S, Solinas SP, Cravanzola C, Vargiu C, Grillo MA, Colombatto S. Transport and metabolism of agmatine in rat hepatocyte cultures. Eur J Biochem. 2001;268:940-947.

2. Gilad GM, Salame K, Rabey JM, Gilad VH. Agmatine treatment is neuroprotective in rodent brain injury models. Life Sci. 1995;58:41-46.

3. Yesilyurt O, Uzbay IT. Agmatine potentiates the analgesic effect of morphine by an $\alpha 2$-adrenoceptor-mediated mechanism in mice. Neuropsychopharmacology. 2001;25:98-103.

4. Zomkowski AD, Hammes L, Lin J, Calixto JB, Santos AR, Rodrigues AL. Agmatine produces antidepressant-like effects in two models of depression in mice. Neuroreport. 2002;13:387-391.

5. Uzbay T. A new target for diagnosis and treatment of CNS disorders: agmatinergic system. Curr Med Chem. 2012;19:5116-5121. 
6. Uzbay T. The pharmacological importance of agmatine in the brain. Neurosci Biobehav Rev. 2012;36:502-519.

7. Geyer MA, Krebs-Thomson K, Braff DL, Swerdlow NR. Pharmacological studies of prepulse inhibition models of sensorimotor gating deficits in schizophrenia: a decade in review. Psychopharmacology. 2001;156:117154.

8. Uzbay T, Kayir H, Goktalay G, Yildirim M. Agmatine disrupts prepulse inhibition of acoustic startle reflex in rats. J Psychopharmacol. 2010;24:923-929.

9. Uzbay T, Goktalay G, Kayir H, Eker SS, Sarandol A, Oral S, Buyukuysal L, Ulusoy G, Kirli S. Increased plasma agmatine levels in patients with schizophrenia. J Psychiatr Res. 2013;47:1054-1060.

10. Tabor CW, Rosenthal SM. Pharmacology of spermine and spermidine; some effects on animals and bacteria. J Pharmacol Exp Ther. 1956;116:139-155.

11. De Vera N, Serratosa J, Artigas F, Martínez E. Toxic effects of putrescine in rat brain: Polyamines can be involved in the action of excitotoxins. Amino Acids. 1992;3:261-269.

12. Creaven PJ, Perez R, Pendyala L, Meropol NJ, Loewen G, Levine E, Berghorn E, Raghavan D. Unusual central nervous system toxicity in a phase I study of N1N11 diethylnorspermine in patients with advanced malignancy. Invest New Drugs. 1997;15:227-234.

13. Ray RM, Viar MJ, Yuan Q, Johnson LR. Polyamine depletion delays apoptosis of rat intestinal epithelial cells. Am J Physiol Cell Physiol. 2000;278:480-489.

14. Sharmin S, Sakata K, Kashiwagi K, Ueda S, Iwasaki S, Shirahata A, Igarashi K. Polyamine cytotoxicity in the presence of bovine serum amine oxidase. Biochem Biophys Res Commun. 2001;282:228-235.

15. Wilding G, King D, Tutsch K, Pomplun M, Feierabend C, Alberti D, Arzoomanian R. Phase I trial of the polyamine analog N1, N14diethylhomospermine (DEHSPM) in patients with advanced solid tumors. Invest New Drugs. 2004;22:131-138.

16. Wunderlichová $L$, Buňková $L$, Koutný $M$, Jančová $P$, Buňka F. Formation, degradation, and detoxification of putrescine by foodborne bacteria: a review. Compr Rev Food Sci Food Safety. 2014;13:1012-1030.

17. Silla Santos MH. Biogenic amines: their importance in foods. Int J Food Microbiol. 1996;29:213-231.

18. Halász A, Baráth Á, Holzapfel WH. The biogenic amine content of beer; the effect of barley, malting and brewing on amine concentration. $Z$ Lebensm Unters F A. 1999;208:418-423.

19. Ibe A, Saito K, Nakazato M, Kikuchi Y, Fujinuma K, Nishima T. Quantitative determination of amines in wine by liquid chromatography. J Assoc Anal Chem. 1990;74:695-698.

20. Galgano F, Caruso M, Favati F, Romano P. HPLC determination of agmatine and other amines in wine. $\mathrm{J}$ Int Sci Vigne Vin (France). 2003;37:237-242.

21. Berenholz L, Segal S, Gilad VH, Klein C, Yehezkeli E, Eviatar E, Kessler A, Gilad GM. Agmatine treatment and vein graft reconstruction enhance recovery after experimental facial nerve injury. J Peripher Nerv Syst. 2005;10:319-328.

22. Halaris A, Plietz J. Agmatine: metabolic pathway and spectrum of activity in brain. CNS Drugs. 2007;21:885-900.

23. Gilad GM, Gilad VH. Long-term ( 5 years), high daily dosage of dietary agmatine evidence of safety: a case report. J Med Food. 2014;17:12561259.
24. Miller-Fleming L, Olin-Sandoval V, Campbell K, Ralser M. Remaining mysteries of molecular biology: The role of polyamines in the cell. J Mol Biol. 2015;427:3389-3406.

25. Williams K. Interactions of polyamines with ion channels. Biochem J. 1997;325:289-297.

26. Bettuzzi S, Davalli P, Astancolle S, Pinna C, Roncaglia R, Boraldi F, Tiozzo R, Sharrard M, Corti A. Coordinate changes of polyamine metabolism regulatory proteins during the cell cycle of normal human dermal fibroblasts. FEBS Lett. 1999;446:18-22.

27. Davidson NE, Hahm HA, McCloskey DE, Woster PM, Casero RA Jr. Clinical aspects of cell death in breast cancer: the polyamine pathway as a new target for treatment. Endocr Relat Cancer. 1999;6:69-73.

28. Tabib A, Bachrach $U$. Role of polyamines in mediating malignant transformation and oncogene expression. Int J Biochem Cell Biol. 1999;31:1289-1295.

29. Hou MH, Lin SB, Yuann JM, Lin WC, Wang AH, Kan Ls L. Effects of polyamines on the thermal stability and formation kinetics of DNA duplexes with abnormal structure. Nucleic Acids Res. 2001;29:51215128.

30. Kaur-Sawhney R, Tiburcio AF, Altabella T, Galston AW. Polyamines in plants: an overview. J Cell Mol Biol. 2003;2:1-12.

31. Pegg AE. Toxicity of polyamines and their metabolic products. Chem Res Toxicol. 2013;26:1782-1800.

32. Zou T, Rao JN, Liu L, Xiao L, Cui YH, Jiang Z, Ouyang M, Donahue JM, Wang JY. Polyamines inhibit the assembly of stress granules in normal intestinal epithelial cells regulating apoptosis. Am J Physiol Cell Physiol. 2012;303:102-111.

33. Raasch W, Schäfer U, Qadri F, Dominiak P. Agmatine, an endogenous ligand at imidazoline binding sites, does not antagonize the clonidinemediated blood pressure reaction. Br J Pharmacol. 2002;135:663-672.

34. Piletz JE, Aricioglu F, Cheng JT, Fairbanks CA, Gilad VH, Haenisch B, Halaris A, Hong S, Lee JE, Li J, Liu P, Molderings GJ, Rodrigues AL, Satriano J, Seong GJ, Wilcox G, Wu N, Gilad GM. Agmatine: clinical applications after 100 years in translation. Drug Discov Today. 2013;18:880-893.

35. Keynan O, Mirovsky Y, Dekel S, Gilad VH, Gilad GM. Safety and efficacy of dietary agmatine sulfate in lumbar disc-associated radiculopathy. An open-label, dose-escalating study followed by a randomized, doubleblind, placebo-controlled trial. Pain Med. 2010;11:356-368.

36. Gilad GM, Gilad VH. Evidence for oral agmatine sulfate safety a 95-day high dosage pilot study with rats. Food Chem Toxicol. 2013;62:758-762.

37. Rushaidhi M, Collie ND, Zhang H, Liu P. Agmatine selectively improves behavioural function in aged male Sprague-Dawley rats. Neuroscience. 2012;218:206-215.

38. Rushaidhi M, Zhang H, Liu P. Effects of prolonged agmatine treatment in aged male Sprague-Dawley rats. Neuroscience. 2013;234:116-124.

39. Shimizu H. Shimizu's Textbook of Dermatology. 1st ed. Hokkaido-Japan: Hokkaido University Press, Nakayama Shoten, 2007.

40. Nayak S, Acharjya B. Adverse cutaneous drug reaction. Indian J Dermatol. 2008;53:2-8.

41. Adam J, Pichler WJ, Yerly D. Delayed drug hypersensitivity: models of T-cell stimulation. Br J Clin Pharmacol. 2011;71:701-707.

42. Dearman RJ, Kimber I. Factors influencing the induction phase of skin sensitization. Am J Contact Dermat. 2003;14:188-194. 
43. Alvarez-Sánchez R, Basketter D, Pease C, Lepoittevin JP. Studies of chemical selectivity of hapten, reactivity, and skin sensitization potency. 3. Synthesis and studies on the reactivity toward model nucleophiles of the 13C-labeled skin sensitizers, 5-chloro-2-methylisothiazol-3-one (MCl) and 2-methylisothiazol-3-one (MI). Chem Res Toxicol. 2003;16:627636.

44. Alleva FR, Balazs T. Toxic effects of postnatal administration of streptomycin sulfate to rats. Toxicol Appl Pharmacol. 1978;45:855-859.

45. Habs M, Schmähl D. Carcinogenicity of bleomycin sulfate and peplomycin sulfate after repeated subcutaneous application to rats. Oncology. 1984;41:114-119.

46. Zeltser R, Valle L, Tanck C, Holyst MM, Ritchlin C, Gaspari AA. Clinical, histological, and immunophenotypic characteristics of injection site reactions associated with etanercept: a recombinant tumor necrosis factor alpha receptor: Fc fusion protein. Arch Dermatol. 2001;137:893899.

47. Lalezari JP, Henry K, O'Hearn M, Montaner JS, Piliero PJ, Trottier B, Walmsley S, Cohen C, Kuritzkes DR, Eron JJ Jr, Chung J, DeMasi R, Donatacci L, Drobnes C, Delehanty J, Salgo M; TORO 1 Study Group. Enfuvirtide, an HIV-1 fusion inhibitor, for drug-resistant HIV infection in North and South America. N Engl J Med. 2003;348:2175-2185.
48. Dalmau J, Pimentel CL, Puig L, Peramiquel L, Roe E, Alomar A. Cutaneous necrosis after injection of polyethylene glycol-modified interferon alfa. J Am Acad Dermatol. 2005;53:62-66.

49. Bavbek S, Ataman Ş, Bankova L, Castells M. Injection site reaction to adalimumab: Positive skin test and successful rapid desensitisation. Allergol Immunopathol (Madr). 2013;41:204-206.

50. Kurzen H, Petzoldt D, Hartschuh W, Jappe U. Cutaneous necrosis after subcutaneous injection of polyethylene-glycol-modified interferon alpha. Acta Derm Venereol. 2002;82:310-312.

51. Rosina P, Girolomoni G. Cutaneous necrosis complicating the injection of pegylated interferon alpha-2b in a patient with chronic hepatitis $\mathrm{C}$. Acta Dermatovenerol Croat. 2008;16:35-37.

52. Faghihi G, Basiri A, Pourazizi M, Abtahi-Naeini B, Saffaei A. Multiple cutaneous necrotic lesions associated with Interferon beta-1b injection for multiple sclerosis treatment: A case report and literature review. J Res Pharm Pract. 2015;4:99-103.

53. Issa AA, Simman R. Lovenox induced tissue necrosis, a case report and literature review. J Am Coll Clin Wound Spec. 2015;5:66-68. 